\title{
How Patients and Nurses defined Advocacy in Nursing? A Review of the Literature
}

\author{
Elsa Vitale $^{1^{*}} \quad$ Francesco Germini $^{2} \quad$ Michele Massaro $^{3} \quad$ Rosa Silvia Fortunato ${ }^{4}$ \\ 1.PhD, MSN, BSN, ASL Bari, Italy \\ 2.MSN, BSN, RN, ASL Bari, Italy \\ 3.MSN, BSN, ASL Bat, Italy \\ 4.BSN, RN, ASL Bologna, Italy
}

\begin{abstract}
Objectives: Advocacy is an important aspect in current professional nursing care and it is a relatively new role for nursing, emerged in the United States in 1980s. This article aimed to explore the basis of advocacy concept viewed by both nurses and patients.Design: A computerized search in PubMed, Medline, Embase databases was conducted to highlight the relevance of nursing advocacy by nurses and patients. This review included qualitative studies which explained better advocacy concept in nursing practice and analyzed the concept of nursing advocacy. Data sources: Fifteen articles were found. Of these, only six met all the requirements of the inclusion criteria Review methods: Articles were compared by considering for each paper the purpose, the design, the methodology, the finding, in order to define advocacy concept by both patients and nurses.Results: Six articles were found, which were published between 1996 and 2018.Conclusions: It was found that the concept and the practice of the nursing advocacy was still enshrouded in confusion, conflict and change.
\end{abstract}

Keywords: Advocacy; Nursing Advocacy; Literature Review; Patient Advocacy.

DOI: $10.7176 / \mathrm{JHMN} / 63-08$

Publication date:June $30^{\text {th }} 2019$

\section{Introduction}

Advocacy, as defined in a dictionary, describes "the act of pleading for, supporting, urging by argument, recommending publicly, and active espousal". Inherent to the definition of the term is the concept of action. Advocacy implies taking action to achieve a goal, either on behalf of oneself or on behalf of another. In nursing, it is directly related to patient care, with the patient's needs or wishes often serving as the impetus for, or defining feature of, the advocacy itself.

Advocacy is an important aspect in current professional nursing care, both for nurses and patients. The nurse represents a moral agent of the patient, so he must be ready and able to advocate for the patient's needs

Nursing has not always practiced advocacy; rather, advocacy is a relatively new role for nursing, emerging in the United States in 1980s. Much of the philosophical work has formed the basis of advocacy. For example, "Curtin, 1979" based her philosophy of nursing advocacy on the belief that the humanity of each individual came forth from human needs. The nurse, according to Curtin, provided a supportive atmosphere for the patient' $s$ decision - making process, which was the basis of all other nursing activities. As human advocates, nurses assist patient to discover the significance of their life process.

Moreover, "Gadow, 1980" had a similar philosophy of nursing advocacy, which she called existential advocacy. Gadow described existential advocacy as the nurse' s assistance to patients in exercising the client' $s$ right of self - determination, utilizing judgments that realize the complexity of the patient's value. She argued that only patient could decide what was in his or her own best interest, and that nurse was entirely engaged in assisting the patient in this process. Gadow also has explored advocacy for the vulnerable patient, concluding that nurses have a moral commitment in regards to a patient' s autonomy.

In addition, "Kohnke, 1980" viewed the role of nurse advocate as having two functions: that of an informer to the patient and as supporter of the patient' s decision. Both these functions of nurse advocacy carry the risk of alienating the nurse advocate in regards to other healthcare professionals. Kohnke revealed that for a nurse to be proficient as a nurse advocate, the nurse might have an adequate knowledge based in areas such as ethics, social law, and politics.

Understanding advocacy, as an essential component of nursing practice, is the first step in becoming a patient advocate. Many nurses do not feel that they have the power or autonomy to take action for patients.

The code for nursing identifies the responsibility for advocacy, and yet nurses often are not supported by their employers in this .

This literature review is focused on the relevance of the advocacy concept in the nursing practice and both in the patient perception.

\section{Methods}

A computerized search in PubMed, Medline, Embase databases was conducted between 1996 and 2018. The search 
was limited to scientific literature published in English language. Keywords were: Advocacy; Nursing Advocacy; Literature Review; Patient Advocacy.

Additionally, only papers which met the inclusion criteria were included.

Inclusion criteria:

- Qualitative studies;

- Studies that defined advocacy in practicing nurses;

- Concept analyses nursing advocacy .

Exclusion criteria:

- Studies highly specific in the advocacy topic;

- Studies analyzing advocacy perception by only patients' sides;

- Studies analyzing only rational ethic in nursing advocacy.

Fifteen articles were found. Titles and year of publication were organized into a database. All the redundant concept title articles found were not considered. Among them, only the most recent article was taking into account for this review. Finally, six articles, which better respected the inclusion and the exclusion criteria above mentioned, were included in this review.

\section{Results}

Six articles were found, which were published between 1996 and 2012. These papers better defined the advocacy concept by nurses and by patients. The Table 1 showed the conceptual definition of nursing advocacy developed by the comparison of the six articles found.

As regards advocacy in nursing, in 1996 Mallik studied the interpretation of patient advocacy by practicing nurses. In this study focus group interviews were used, which allowed respondents to recount and share their particular stories of patient advocacy. Results indicated that a triadic model of advocacy predominated which involved the nurse in a conflict or in a potential conflict situation. The patient's requests, the patient's fear, the patent's vulnerability or threats to the patient's human rights provoked an advocacy response in the perceptive nurse. The nurse was sustained in the role through patient recognition, the nurse-patient relationship, emotional strength, moral justification and knowledge or expertise legitimacy.

In 1998 Chafey at al. explored nurses' views of patients advocacy in a qualitative study. Seventeen hospital and community nurses were interviewed to determine whether and how they exercise the advocacy role and what they believed to promote or to impede the advocacy practice. Results suggested that the advocacy role was not uppermost in the minds of many of the participants. However, the nurse-patient relationship emerged as an important feature of advocacy. Teaching, informing and supporting were frequent activities of nursing advocacy; while, issues of accountability and ethics were central to the advocacy process. Furthermore, nursing advocacy barriers existed, as: time, economics, acuity and power hierarchies, combined with factors as lack of autonomy and fatigue.

In 2000 Mallik and Rafferty composed a bolometric analysis of articles cited under the key descriptor "patient advocacy" in the International Nursing Index. Only articles from the USA and the UK were considered. Findings showed most important a role in patient advocacy was proposed in the American nursing literature in the late 1970s and in the British literature a decade later. Support for the role was evident in its use in professional organizations and schools. The pattern of dissemination illustrated the influence of American nursing on the professional role of nurses in the UK.

In 2002 Foley et al. described how nurse developed the skill of advocating for patients. An hermeneutic phenomenological research was conducted. Both reserve and active U.S. Army nurses who cared for patients associated with the military operation in Bosnia were individually interviewed to understand their experiences of advocating for patients and how they developed their advocating practices. The constitutive pattern identified was Developing Advocating Practices. The themes comprising the answers: "who I am"; "Watching other nurses interact with patients"; "Gaining confidence". For the nurses, in this study, developing advocating practices was more haphazard and situationally dependent than methodologically method and they taught that advocacy in nursing depended from nursing education in this task.

In 2006 MacDonald discussed the advocacy concept by reviewing some qualitative studies that focused on nurses' experiences with advocacy in practice. This study revealed important themes in relation to factors that influence the application of advocacy in nursing practice. Evidence suggested that the nature and context of relationships played a significant role in influencing the enactment of advocacy.

Finally, in 2007 Hanks highlighted the barriers to nursing effective advocacy. This concept analysis of barriers to nursing advocacy used the walker and avant method of concept analysis. By analyzing the barriers to effective nursing advocacy for clients, nursing can then find strategies to manage those barriers and maximize the nurse's advocacy efforts. 
Table 1. The literature comparison

\begin{tabular}{|c|c|c|c|c|c|c|}
\hline Title & $\begin{array}{l}\text { Advocacy in } \\
\text { nursing } \\
\text { perceptions } \\
\text { of } \\
\text { practicing } \\
\text { nurses } \\
\end{array}$ & $\begin{array}{l}\text { Characterization } \\
\text { of Advocacy by } \\
\text { Practicing } \\
\text { Nurses }\end{array}$ & $\begin{array}{l}\text { Diffusion of the } \\
\text { Concept } \\
\text { Patient Advocacy }\end{array}$ & $\begin{array}{l}\text { How } \quad \text { Nurses } \\
\text { Learn Advocacy }\end{array}$ & $\begin{array}{l}\text { Relational } \\
\text { ethics } \\
\text { advocacy and } \\
\text { nursing: } \\
\text { literature } \\
\text { review }\end{array}$ & $\begin{array}{l}\text { Barriers } \\
\text { Nursing } \\
\text { Advocacy: A } \\
\text { Concept Analysis }\end{array}$ \\
\hline Author(s) & $\begin{array}{l}\text { Maggie } \\
\text { Mallik }\end{array}$ & $\begin{array}{lr}\text { Kathleen } & \text { Chafey; } \\
\text { Marty } & \text { Rhea; } \\
\text { Anna } & \text { M. } \\
\text { Shannon; } & \text { Sandra } \\
\text { Spender } & \end{array}$ & $\begin{array}{lr}\text { Maggie } & \text { Mallik; } \\
\text { Anne } & \text { Marie } \\
\text { Rafferty } & \end{array}$ & $\begin{array}{lr}\text { Barbara Jo Foley; } \\
\text { M. } & \text { Polene } \\
\text { Minick; } & \text { Carolyn } \\
\text { C. Kee } & \end{array}$ & $\begin{array}{l}\text { Hannah } \\
\text { MacDonald }\end{array}$ & Robert G. Hanks \\
\hline $\begin{array}{l}\text { Publication } \\
\text { year }\end{array}$ & 1996 & 1998 & 2000 & 2002 & 2006 & 2007 \\
\hline Keywords & $\begin{array}{l}\text { Focus group; } \\
\text { Patient } \\
\text { advocacy; } \\
\text { Protecting; } \\
\text { "Stories"; } \\
\text { Triadic } \\
\text { conflict } \\
\text { model } \\
\end{array}$ & $\begin{array}{l}\text { Advocacy; } \\
\text { Autonomy; } \\
\text { Environment; } \\
\text { Professional role }\end{array}$ & $\begin{array}{l}\text { Patient advocacy; } \\
\text { Diffusion; } \\
\text { Innovation; } \\
\text { Bibliometric } \\
\text { analysis }\end{array}$ & $\begin{array}{l}\text { Nursing; } \\
\text { Advocacy }\end{array}$ & $\begin{array}{l}\text { Advocacy; } \\
\text { Literature } \\
\text { review; } \\
\text { Nursing; } \\
\text { Qualitative } \\
\text { research; } \\
\text { Rational ethics }\end{array}$ & $\begin{array}{l}\text { Barriers; } \\
\text { Concept analysis; } \\
\text { Nursing; } \\
\text { Patient advocacy }\end{array}$ \\
\hline Purpose & $\begin{array}{l}\text { To examine } \\
\text { patient } \\
\text { advocacy by } \\
\text { practicing } \\
\text { nurses }\end{array}$ & $\begin{array}{l}\text { To explore } \\
\text { nurses' views of } \\
\text { patient advocacy }\end{array}$ & $\begin{array}{l}\text { To examine the } \\
\text { growth and } \\
\text { diffusion through } \\
\text { the USA and the } \\
\text { UK literature of } \\
\text { nurses' claims to } \\
\text { patient advocacy }\end{array}$ & $\begin{array}{l}\text { To } \\
\text { "How" nurses } \\
\text { develop the shill } \\
\text { of advocating for } \\
\text { patients }\end{array}$ & $\begin{array}{l}\begin{array}{l}\text { To analyze } \\
\text { themes from }\end{array} \\
\text { accounts of } \\
\text { nurses' } \\
\text { experiences with } \\
\text { advocacy that } \\
\text { may expand the } \\
\text { understanding of } \\
\text { advocacy in } \\
\text { nursing practice }\end{array}$ & $\begin{array}{l}\text { To provide clarity } \\
\text { and direction for } \\
\text { future inquires } \\
\text { into the concept of } \\
\text { barriers to nursing } \\
\text { advocacy }\end{array}$ \\
\hline Design & $\begin{array}{l}\text { Qualitative } \\
\text { study - focus } \\
\text { group } \\
\text { interviews }\end{array}$ & $\begin{array}{l}\text { Qualitative } \\
\text { descriptive study }\end{array}$ & $\begin{array}{l}\text { Bibliometric } \\
\text { analysis of articles } \\
\text { cited under the key } \\
\text { descriptor "patient } \\
\text { advocacy" in the } \\
\text { International } \\
\text { Nursing Index, } \\
\text { (INI) }\end{array}$ & $\begin{array}{l}\text { Hermeneutic } \\
\text { phenomenological } \\
\text { research }\end{array}$ & $\begin{array}{l}\text { Qualitative study } \\
\text { based on the } \\
\text { nurses, } \\
\text { experiences with } \\
\text { advocacy in } \\
\text { practice }\end{array}$ & $\begin{array}{l}\text { Concept analysis } \\
\text { study }\end{array}$ \\
\hline Method & $\begin{array}{l}\text { Collection of } \\
\text { data by a } \\
\text { recount of } \\
104 \\
\text { particular } \\
\text { stories of } \\
\text { patient } \\
\text { advocacy }\end{array}$ & $\begin{array}{l}\text { Administration of } \\
\text { a standardized } \\
\text { open }- \text { ended } \\
\begin{array}{l}\text { interview to } 17 \\
\text { nurses }\end{array}\end{array}$ & $\begin{array}{l}\text { Titles, countries of } \\
\text { origin of the } \\
\text { journal, year of } \\
\text { publication were } \\
\text { organized into a } \\
\text { database to } \\
\text { provide } \\
\text { quantitative } \\
\text { material } \\
\text { comparative } \\
\text { output from the } \\
\text { USA and the UK }\end{array}$ & $\begin{array}{l}\text { Interview to U.S. } \\
\text { army nurses who } \\
\text { cared for patients } \\
\text { associated with } \\
\text { the military } \\
\text { operation in } \\
\text { Bosnia to gain an } \\
\text { understanding of } \\
\text { their experiences } \\
\text { of advocating for } \\
\text { patients and how } \\
\text { they developed } \\
\text { their advocating } \\
\text { practices }\end{array}$ & $\begin{array}{l}\text { Review } \\
\text { articles on the } \\
\text { CINAHL and } \\
\text { Academic Search } \\
\text { Premier } \\
\text { databases }\end{array}$ & $\begin{array}{l}\text { The Walker and } \\
\text { Avant } \\
\text { methodology, } \\
\text { derived from the } \\
\text { Wilson's classic } \\
\text { concept analysis } \\
\text { procedure }\end{array}$ \\
\hline Finding & $\begin{array}{l}\text { Triadic } \\
\text { model of } \\
\text { advocacy }\end{array}$ & $\begin{array}{l}\text { The advocacy role } \\
\text { was not } \\
\text { uppermost in the } \\
\text { minds of many of } \\
\text { the nurses }\end{array}$ & $\begin{array}{l}\text { The pattern of } \\
\text { dissemination } \\
\text { demonstrated the } \\
\text { influence of } \\
\text { American nursing } \\
\text { on the professional } \\
\text { role of nurses in } \\
\text { the UK }\end{array}$ & $\begin{array}{l}\text { The constitutive } \\
\text { pattern identified } \\
\text { was Developing } \\
\text { Advocating } \\
\text { Practices }\end{array}$ & $\begin{array}{l}\text { Nurses' } \\
\text { experiences with } \\
\text { advocacy reveal } \\
\text { important themes } \\
\text { in relation to } \\
\text { factors that } \\
\text { influence the } \\
\text { application of } \\
\text { advocacy in } \\
\text { nursing practice }\end{array}$ & $\begin{array}{l}\text { It represents a } \\
\text { concept analysis } \\
\text { on the barriers to } \\
\text { nursing advocacy } \\
\text { in order to clarify } \\
\text { the concept and } \\
\text { provide a basis for } \\
\text { further research } \\
\text { into the barriers of } \\
\text { nursing advocacy }\end{array}$ \\
\hline Conclusion & $\begin{array}{l}\text { The triadic } \\
\text { model } \\
\text { emphasized } \\
\text { patients' } \\
\text { needs } \\
\text { choices }\end{array}$ & $\begin{array}{l}\text { The conceptual } \\
\text { model of patient } \\
\text { advocacy was a } \\
\text { critical dimension } \\
\text { of professional } \\
\text { nursing that was } \\
\text { changing rapidly }\end{array}$ & $\begin{array}{l}\text { Patient advocacy } \\
\text { has reached as an } \\
\text { innovation in } \\
\text { nursing }\end{array}$ & $\begin{array}{l}\text { Nurses will have a } \\
\text { stronger } \\
\text { foundation in } \\
\text { education } \\
\text { advocacy }\end{array}$ & $\begin{array}{l}\text { The application } \\
\text { of advocacy in } \\
\text { nursing practice } \\
\text { was complex }\end{array}$ & $\begin{array}{l}\text { Nursing } \\
\text { claimed } \\
\text { advocacy as an } \\
\text { important client } \\
\text { component of } \\
\text { nursing practice }\end{array}$ \\
\hline
\end{tabular}




\section{Discussion}

By considering all these works it was emerged that the concept and the practice of the nursing advocacy was still enshrouded in confusion, conflict and change. Confusion surrounding the concept of advocacy centers on the absence of a consistent model defining the parameters of advocacy in professional practice. As "Jezewski, 1993" observed the "complexity of advocacy in nursing was exemplified by its many descriptions in the nursing literature".

Specifically, in the "Mallik, 1996" study the interpretation of data collected in the focus group showed that practicing nurses did recognize and could demarcate the phenomenon labeled as patient advocacy. In fact, it was evident that respondents appeared to accept the role as a legitimate part of their work. Although individual perceptions of what constituted an advocacy activity differed. It was possible through the analysis of the stories to suggest a "model case" for the role, for example a conflict-potential triadic model of advocacy. A dyalic model, where nurse gave information, advice and support, was rejected because the essential element of "pleading a cause" was not present. Other labels, such as counseling, educating and information giving, could be attached to these latter activities. From the results of this study, reasons for maintaining the patient in a passive mode could be ascribed to the cultural attitudes of both the nurse and the patient. So, the dominant model that emerged from the Mallik' s analysis was the triadic conflict model of advocacy, which involved the nurse in a conflict, better in a potential conflict situation. In fact, the patients' requests, the patients' fear, the patients' vulnerability or threats to the patients' human rights provoked and advocacy response in the perceptive nurse. Moreover, the adoption of a triadic model of patient advocacy could protect the patient and would ultimately be professionally more enhancing for nurses. Finally, the results of this study cannot be generalized and it was hoped that it will stimulate further research to determine the validation of legitimacy of the claim to patient advocacy by nurses.

Moreover, in the "Chafey et al, 1998" work all the results suggested that there were three categories of characteristics that helped to determine when, if and how client advocacy was practiced by a professional nurse. These independent categories were the client, the nurse and the environment. The characteristics of any category could dominate the other two, making advocacy occur or not occur. The occurrence of advocacy seemed to require a client who was unable to mediate satisfaction of his or her own needs, a nurse with the traits to support her advocacy, and an environment that could overwhelm neither. The model that evolved from the data conveys the complexities and contextual depth in which practicing nurses view advocacy. The model presented categories and characteristics that show the fluid nature of their interaction. The proposed model also provided a conceptual framework for follow-up studies. Furthermore, it emerged that the advocacy role was a critical, but unique dimension of professional nursing that is chancing rapidly and might be diverging from the usual role prescribed in the professional literature and taught in baccalaureate nursing curricula.

Additionally, in the "Mallik et al, 2000" study the bibliometric analysis of the literature was to trace the diffusion of patient advocacy as an innovation within the nursing profession. Although patients' rights were a predominant issue in all the journal articles sampled, only nurses in the USA and in the UK took up the challenge of the advocacy role. Literature analyzed was confined to the output of one professional group in health care delivery. Although nurses could have had their own internal agenda, they did not exist in isolation, and being usually more reactive than proactive may reflect the macro movements in health care delivery. Therefore, the most significant limitation of this bibliometric review was the lack of contextual analysis of concurrent events within health care systems. Social changes, brought about by the fight for Civil Rights in the USA in the 1960s, could have been catalysts for major changes in the traditional functioning of health care institutions. These changes might have led to the emergence of the patients' rights movement with a focus on advocacy activities and their relative growth in health care during the late 1970s and early 1980s. Political conservatism both in the USA and the UK could account for the decline in citations linked with regards in advocacy from the mid to late 1980s. The upsurge in publications in the USA in the 1990s might reflect continuing frustrations with problems to access and equity in the receipt of health care and preoccupation with consumerism. Managerialism and consumerism in the British context led to the production of "patient charters" in the early 1990s. This change might have been mirrored in the increase in literature on patients' rights and advocacy that occurred in the UK nursing journal in the early 1990s. However, this study was not a sociological analysis of advocacy, but it included literature generated mainly by nursing academics. In fact, theorists and educators in nursing formed their own sociocultural elite and spread their messages via journals. They formed a closed community with shared attitudes, beliefs and conceptual schema. In the article written by British authors on advocacy, the work of key American authors could be detected. The American influence on nursing ideas in Britain seemed significant with little evidence of two way traffic. This finding would appear to confirm "Corin' s, 1984" contention, in discussing the science literature, that Americans were ethnocentric in their citation patterns compared with authors from other countries.

In the "Foley et al, 2002" study the advocating role of nurse was considered essential, little in the nursing literature indicated how nurses learn this role. In this study, nurses' recollections of their experiences showed three ways of developing advocacy in their nursing practice: who they were as people, watching other nurses interact with patients, and gaining confidence. Many of the nurses believed that "standing up for others" was a part of their 
being and had been so for as long as they might hear the word advocacy for the first time, they might recognize the concept. Nursing faculty might need to define advocacy in relationship to patient care rather than teach a new idea. "Benner, 1991" wrote that care giving practices did not come naturally but were skills learned first in families and communities and later in school and work. Some of the participants in the current study were able to recognize that they had learned care and concern from their families and communities. Their nursing faculty taught them how to best apply this skill in a different context, the care of patients. Watching other nurses interacted with patients was also a method for developing advocacy. So, students needed to see positive role modeling in other nurses, such as expert clinicians, head nurses and clinical nurses specialists. Students were eager to learn and much of their learning in clinical situations came from watching how registered nurses practice. Dialog with students during clinical rotations was an important aspect of learning. "Benner, 1991" explained "watching other nurses interact with patients" well when she sad, "One could be placed in the situation with the best preparation for noticing qualitative distinctions about involvement and caring, suffering, hope and recovery, but the final lesson might come from actual dialogue in actual situations". Nursing students might experience these concepts in order to internalize them. Such knowledge was also produced through dialog with people with different perspectives, "Taylor, 1989". Multiple perspectives of a situation helped to illuminate taken - for - granted skills and practices, further emphasizing the importance of communication among colleagues. This thinking was expressed by "Diekelmann, 1991", who said that nurses needed both to make stories of practice visible for themselves and to share them with colleagues. Participants also described gaining confidence as the third way of developing advocacy. Gaining confidence could begin in nursing education programs, but was more often part of a new graduate' s practice. The theme of gaining confidence also implied that experienced nurses guide young nurses in making clinical judgment. New nurses needed validation that their practice was correct. Experienced nurses could consciously help new nurses learn advocacy through preceptorships or one - to - one mentoring.

The "Mac Donald's, 2000 study advocacy in nursing was recognized as a worthy activity and, according to professional codes of ethics, a moral imperative. Until this work it was already known the definitions of advocacy; the concept that advocacy was a professional expectation and the lack of clarity existed regarding the nature and the scope of the role of advocacy in nursing. Additionally, this study added the concept of the relational context, which had a powerful role in influencing nurses' advocacy actions; the discussion of relational ethics which could further the understanding of advocacy in nursing and, lately the development of nurses' role as advocate which required knowledge of relational ethics, and skill development in relationship - building and navigation of workplace cultures. Further research will be essential to the continued development of the understanding of advocacy. In particular, research employing a greater variety of empirical methods would assist in achieving a more comprehensive understanding of advocacy in nursing. As the role of nurses evolved with respect to direct patient - care, research could reveal new insights about the particular nature in nursing practice.

In the "Hanks' s 2006, study" barriers to nursing advocacy were directly measured. The implications for nursing practice were that nurses needed to overcome barriers to become effective nursing advocates for their clients. Although this was an ideal situation, the threat of job loss, retribution, intimidation or ostracism could be real barriers (Miller et al., 1983; Walsh, 1985). Nurses needed strategies to overcome barriers so that they could seek what was best for the client, including advocating in light of institutional and interdisciplinary constraints (Hewitt, 2002; Kohnke, 1980; Miller at al. 1983). Nursing education had an important role in educating student nurses on the role of client advocacy in nursing and how to effectively manage the barriers to be successful nursing advocates for the client ("Pankratz \& Pankratz, 1974). This educational approach could include not only the student nurse in the prelicensure program but continuing education for the practicing nurse.

\section{Conclusion}

Advocacy in nursing is recognized as an essential activity in the nursing activity. Nursing literature has served works on philosophical stances on nursing advocacy. As a valued and expected activity in nursing the concept of advocacy needed further future clarification in the nurse role as patient advocating. Further research will clarify the limits in nursing advocacy to not damage the patients' rights and their rights as regards to their independence in order to choose alone for themselves. Specifically, research employing a greater variety of empirical methods would assist in achieving a more comprehensive understanding of advocacy in nursing. As the role of nurses evolves with respect to direct patient-care, research could reveal new insights about the particular nature of advocacy in nursing practice.

\section{Acknowledgement}

The authors gratefully acknowledge all studies' authors included in this review for their commitment in this field.

\section{References}

Benner, P. From novice to expert: Excellence \& power in clinical nursing practice. Menlo Park: Addison-Wesley, 1984. 
Benner, $\mathrm{P}$. The role of experience, narrative and community in skilled ethical comportment. Advances in Nursing Science, 1991; 14, 21-20.

Chafey, K., Marty, R., Shannon, A. M., Spencer, S. Characterization of advocacy by practicing nurses. Journal of Professional Nursing, 1998; 14, 43-52.

Corin, B. The citation process -The role and significance of citations in scientific communications. London, Taylor Graham, 1984.

Curtin, L. The nurse as advocate: A philosophical foundation for nursing. Advances in Nursing Science, 1979; $1(3), 1-10$

Diekelmann, N. The emancipatory power of the narrative. New York: The National League for Nursing Press, 1991; 41-62.

Gadow, S. Existential advocacy: Philosophical foundation of nursing. In S. Spicker \& S. Gadow ed. New York: Springer, 1980; $79-101$.

Hanks, R.G. Sphere of Nursing Advocacy Model. Nursing Forum, 2005; 40(3), 75-78.

Hanks, R.G. Barriers to Nursing Advocacy: A Concept Analysis. Nursing Forum, 2007; 42, (4),171-77.

Hewitt, J. A critical review of the arguments debating the role of the nurse advocate. Journal of Advanced Nursing, 2002; 37(5), 439-45.

Kohnke, M. F. The nurse as advocate. American Journal of Nursing, 1980; 80, (11), 2038-40.

MacDonald, H. Relational ethics and advocacy in nursing: literature review. Journal of Advanced Nursing, 2007; $57,(2), 119-26$.

Mallik, M. Advocacy in nursing-perceptions of practising nurses. Journal of Clinical Nursing, 1997; 6, 303-13.

Mallik, M., Rafferty, A. M. Diffusion of the concept of patient advocacy. Journal of Nursing Scholarship, 2000; 32, (4), 399-404.

Miller, B., Mansen, T., Lee, H. Patient advocacy: Do nurses have the power and authority to act as patient advocate? Nursing Leadership, 1983; 6, (2), 56-60.

Pankratz, L., Pankratz, D. Nursing autonomy and patients' rights: Development of a nursing attitude scale. Journal of Health and Social Behavior, 1974; 15, (3), 211-16.

Robinson, M. Patient advocacy and the nurse: Is there a conflict of interest?. Nursing Forum,1985; 22, (2), 58-63.

Taylor, C. Sources of the self. Cambridge, MA: Harvard University Press, 1989.

Vaaratio, H., Leino, K.M., Salantera, S., Suominen, T. Nursing advocacy: how is it defined by patients and nurses, what does it involve and how it is experienced? Scand J Caring Sci, 2006; 20, 282-92.

Walsh, P. Mental health dilemmas. Speaking up for the patient. Nursing Times, 1985; 81, (18), 24-26.

Wilson, J. Thinking with concepts. London: Cambridge University Press, 1963.

Zuckerman, H., Merton., R.H. Patterns of evaluation in science: Institutionalization, structure and functions of the referee system. Minerva, 1971; 66-100. 